\title{
Speech Acts in the EFL Classroom: The Case of Kosova
}

\author{
Dorinë Rakaj, PhD Candidate \\ University of Prizren 'Ukshin Hoti', Prizren, Kosovo \\ E-mail: dorine.rakaj@uni.prizren.com
}

\begin{abstract}
The aim of this study was to investigate speech acts performed by two Access teachers at Mati Logoreci Primary School in Prizren, Kosovo (T1 and T2). This study utilized a qualitative descriptive approach, and the data were collected through recording and note taking. These methods were used to collect the data in order to achieve the aims of this study: 1) types of speech acts and 2) frequency of speech acts performed by teachers. The researcher used Searle's taxonomy of five types of illocutionary acts to analyze 60 utterances performed by Access teachers. The results showed that there were four classifications of speech acts performed by both teachers: representatives $(28.3 \%)$, directives $(41.7 \%)$, expressives $(20 \%)$, commissives $(10 \%)$, and no declarations $(0 \%)$. The study revealed that directives and representatives were the most dominant acts performed by both teachers. Based on the results of the study, it can be concluded that further studies should be conducted in other settings to obtain more comprehensive data regarding speech acts.
\end{abstract}

Keywords: Access program, EFL classrooms, EFL teachers, pragmatics, speech acts

DOI: $10.7176 /$ JLLL/85-01

Publication date: January $31^{\text {st }} 2022$

\section{Introduction}

Pragmatics plays a crucial role in the field of linguistics and in other disciplines such as philosophy, psychology, ethology, ethnology, sociology, and political sciences (Senft, 2014). Pragmatics can be seen as the study of language in given contexts or situations of necessity. According to Yule (2010, p.128), pragmatics is the study of invisible meaning, or how we recognize what is meant even when it is not actually said or done. It analyzes what people mean when they utter utterances. Pragmatics covers presupposition, entailment, implicature, politeness, and speech acts. Speech acts are actions performed via utterances, including more specific labels, such as apology, complaint, promise, or request (Yule, 1995, p. 47). Thus, through their communicative utterances, speakers convey requests, pledges, promises, etc. In line with this, Namaziandost, Hashemifardnia, and Hossein (2019) add that speech acts are in fact speakers' intentions conveyed by utterances. In addition, the speech act theory deals with "the interaction between the speaker and the interlocutor" (Armin \& Salmiah, 2020). Thus, the speaker is the person who gives the message, while the interlocutor/listener is the receiver of the message.

Speech acts are pivotal in teaching and learning process, too. It should be noted that the acts of communicating knowledge such as arranging activities, managing the classroom, and delivering instructions are conducted through lecturer conversations that contain speech acts (Budiant, Pahamzah, \& Baihaqi, 2020). However, there are situations when people are unable to decode the meaning of an utterance, so misinterpretation between the listener and the speaker can result. These situations can happen in the classroom as well. Therefore, in order to avoid misinterpretation during the teaching and learning process in an EFL context, understanding the intended meaning of speech acts is also crucial.

\subsection{Research questions}

1. What is the most dominant speech act in the utterances produced by $\mathrm{T} 1$ ?

2. What is the most dominant speech act in the utterances produced by $\mathrm{T} 2$ ?

\section{Literature review}

What does speech mean? According to The Longman Dictionary, the word speech is defined as "a talk, especially a formal one about a particular subject, given to a group of people.' Similarly, Merriam-Webster's Learner's Dictionary defines speech as "a spoken expression of ideas, opinions, etc., that is made by someone who is speaking in front of a group of people." However, what is a speech act? According to Yule (1995:47), "speech acts are actions performed via utterances." Thus, through their communicative utterances, speakers convey requests, pledges, promises, etc.

Speech act theory is an important theory in the pragmatic study of language (Shi, 2018). It has been widely studied and investigated by scholars and researchers. John Austin, a British philosopher, first introduced the theory of speech acts, also known as Austinian theory, in his work, How to Do Things with Words. Speech act theory was further developed and systematized by John Searle (Tiwery, 2021).

Austin defined the speech act as the procedure of performing different actions while uttering words. When the speaker produces an utterance, he/she uses three acts, and according to Levinson (1983, p. 236), Austin isolates 
three dimensions in which saying something means doing something. The three dimensions of a speech act are:

\begin{tabular}{l|l}
\hline Locutionary act & A locutionary act is the act of saying something \\
\hline Illocutionary act & An illocutionary act is the speaker's intentions of uttering a sentence \\
\hline Perlocutionary act & $\begin{array}{l}\text { A perlocutionary act implies the result or the effect of speaker's utterance } \\
\text { on the hearer or listener }\end{array}$
\end{tabular}

Speech act theorists are primarily interested in speaker intentions: the illocutionary force of utterances (Meyer, 2009). Austin classified the illocutionary act into five categories. His (1962, pp. 150-161) classification of illocutionary acts is as follows:

1) Verdictives are typified by the giving of a verdict, as the name implies, by a jury, arbitrator, or umpire. Examples of this category are: acquit, read something as, find (as a matter of fact, hold (as a matter of law), describe, analyze, etc.

2) Exercitives are acts of power, rights, or influence. Examples of this category are: appoint, degrade, dismiss, order, warn, advise, etc.

3) Commissives commit the speaker to a future course of action. Examples of this category are: promise, vow, guarantee, undertake, intend, give my word, bet, etc.

4) Behabitives are expressions of attitudes to someone else's past conduct, behavior and fortunes. Examples of this category are: compliment, bless, apologize, gratitude, congratulate, etc.

5) Expositives are acts of exposition involving the expounding of views, the conducting of arguments, and the clarifying of usages and of references. Examples of this category are: state, describe, affirm, deny, state, etc. As mentioned above, Searle discussed and developed Austin's theory. He (1979) argued that Austin's classification of speech acts had a number of weaknesses. He claimed there were at least six weaknesses/difficulties regarding Austin's classification of speech acts: 1) there is confusion between verbs and acts, 2) not all verbs are illocutionary verbs, 3) there is too much overlap of the categories, 4) there is too much heterogeneity within the categories, 5) many verbs do not satisfy the definition for the category, and 6) there is no consistent principle of classification (Searle, 1979, p.12). Searle suggested another classification based on three criteria: 1) illocutionary point, 2) direction of fit, and 3) sincerity condition expressed. He proposed the following taxonomy of illocutionary acts (as outlined in Levinson 1983, p. 240):

1) Assertives, which commit the speaker to the truth of the expressed proposition (paradigm cases: asserting, concluding, etc.)

2) Directives, which are attempts by the speaker to get the addressee to do something (paradigm cases: requesting, questioning)

3) Commissives, which commit the speaker to some future course of action (paradigm cases: promising, threatening, offering)

4) Expressives, which express a psychological state (paradigm cases: thanking, welcoming, apologizing, welcoming, congratulating)

5) Declarations, which effect immediate changes in the institutional state of affairs and tend to rely on elaborate extra-linguistic institutions (paradigm cases: excommunicating, declaring war, christening, firing from employment).

However, according to Chankova (2012), Searle's taxonomy suffers from similar weaknesses. Searle also proposed the notion of the indirect speech act "in which the speaker may utter a sentence and mean what he says and also mean another illocution with a different propositional content' (Searle, 1979, p.30). For a speech act to be successful, it needs to satisfy a series of conditions. These conditions are known as 'felicity conditions,' and these conditions are further divided into the following four categories: propositional, content, preparatory, sincerity, and essential (Searle, 1969). Yule (1996:50) reclassified the felicity conditions; these are specifics for each condition:

1) General conditions: the speaker and the hearer understand the language being used.

2) Content conditions: the speaker makes a promise and the content of the promise must be that the speaker will perform some future course of action.

3) Preparatory conditions: in making the promise, the speaker presupposes that he can do the promised act and it is in the hearer's interest to do it.

4) Sincerity conditions: the speaker intends to carry out the future action.

5) Essential conditions: the speaker undertakes to do the promised act.

\subsection{Speech acts in the EFL classroom}

Speeches play an important role in our daily lives, especially in the field of education, when teachers want to interact with students. A classroom is a place where lecturers "consciously use speech acts to make, practically force, students to understand what is being said" (Shaqia \& Anggraini, 2020, p. 39). Directives are speech acts that are frequently used in classroom interactions (Searle, 1969). Teachers use these acts when they want students to do something inside and outside the classroom. Classroom speech acts involve all verbal utterances used as a 
medium in classroom communication (Merdana, Seken, \& Putra). Zayed (2014, p.5) asserts that " the more speech acts are practiced by teachers, the more energetic and interesting the class is'. In addition, teachers use various types of speech acts to express their intention (Budianti, Pahamzah, \& Baihaqi, 2020).

\subsection{Previous studies}

Several previous studies have analyzed and investigated speech acts performed by teachers and students inside and outside the classroom.

Andewil and Waziana (2019) conducted a study on classroom interaction during the teaching and learning process, which included an investigation of the types and functions of speech acts produced by a teacher. The subject of this study was a teacher in SMAN 1 Kalirejo. The results showed that directive speech acts were mostly produced by the teacher compared to other types. The data showed that 33 utterances $(21.2 \%)$ were representative speech acts, 6 utterances $(3.8 \%)$ as expressive speech acts, 112 utterances $(71.8 \%)$ as directive speech acts, and 5 utterances $(3.2 \%)$ as commissive speech acts.

Swandewi, Ramendra, and Juniarta (2018) investigated types of speech acts used by English teachers in teaching and learning processes at SMA Negeri 2 Banjar. Two teachers were the subjects of this study. The most frequent speech act used by teachers was the directive speech act that occurred when the teachers tried to give questions, command, suggest, request, invite, interrupt, motivate, and remind.

In another study conducted by Basra and Thoyyibah (2017), the purpose of this research was to examine the speech acts used by an EFL teacher while teaching. The researchers used Searle's taxonomy of speech acts as an instrument. The findings showed that the directive speech act was mostly used by teachers. The frequency of each type found in this research was: $70 \%$ for directives, $21 \%$ for representatives, $6 \%$ for expressives, and $3 \%$ for commissives.

Rosyada (2020) conducted a recent study on speech acts. This study examined the classification of speech acts used by two English lecturers in online teaching and learning processes in the Study Program of English Language Education (TBI), State Islamic University of Mataram (UIN Mataram). The researcher analyzed the lecturers' utterances based on Searle's theory. The results showed that the speech acts performed by lecturers were representatives $(22 \%)$, directives $(44 \%)$, commissives $(12 \%)$, and expressives $(22 \%)$. The results also indicated that the most dominant speech acts used by lecturers were directives $(44 \%)$.

These four studies cover speech acts in education. It should be noted that all of them are comparable to this research conducted by the researcher. However, there are some differences. First, Andewil and Waziana analyzed speech acts and functions. Second, the research conducted by Basra and Thoyyibah investigated an EFL teacher. Furthermore, Rosyada investigated two EFL lecturers during the online teaching and learning process; however, the environment and context were different

Although several scholars have investigated speech acts in EFL classrooms, little attention has been paid to analyzing speech acts performed by Kosovar teachers. Based on the explanation above, the researcher aimed at investigating two Access teachers regarding speech acts.

\section{Methodology}

\subsection{Research design}

A qualitative descriptive approach was used in this study. According to Dörnyei (2007, p.24), "qualitative research involves data collection procedures that result primarily in open-ended, non-numerical data which is then analyzed primarily by non-statistical methods". The researcher observed the linguistic behavior of teachers in the classroom. The data of this study were collected when the teaching and learning process occurred naturally (Merdana, Seken, \& Putra, 2013).

\subsection{Participants}

This study attempted to analyze the types and frequency of speech acts performed by two Access teachers at Mati Logoreci Primary School in Prizren, Kosovo. The Access Microscholarship Program in Kosovo is funded by the U.S Embassy in Pristina, and implemented by KETNET (Kosova English Teachers' Network). This program provides a foundation of English language skills to bright, economically disadvantaged students, primarily between the ages of 13 to 20, in their home countries. Access programs give participants English skills that may lead to better jobs and educational prospects. Participants also gain the ability to compete for and participate in future exchanges and study in the United States (Department of State, 2004).

\subsection{Data analysis}

To analyze the data, the researcher used Searle's taxonomy of five types of illocutionary acts as an instrument. The observation process was performed by recording and note taking. These methods were used to collect the data in order to achieve the aims of this study: 1) types of speech acts and 2) frequency of speech acts performed by teachers. 
The researcher recorded and observed two meetings. The research was conducted by a single researcher (Sejdiu, 2014). Before analyzing the utterances, the researcher transcribed the utterances performed by both teachers while interacting in the classroom. Finally, the researcher classified the data based on their type and frequency.

\section{Results}

This section shows the findings collected from recordings and note-taking performed by Access teachers during the teaching-learning process. Based on the results of the observation and note-taking, the researcher found 60 speech acts (utterances) made by both Access teachers; 30 utterances produced by T1, and 30 utterances produced by $\mathrm{T} 2$. The researcher classified them based on their type and frequency. The findings of this study are presented in the following tables.

\subsection{First teacher's speech acts (T1)}

Table 1: The frequency and percentage of speech acts produced by $T 1$

\begin{tabular}{|l|c|c|}
\hline \multicolumn{1}{|c|}{ Type of speech acts } & Frequency of utterances & Total percentage \\
\hline Representatives & 12 & $40 \%$ \\
\hline Directives & 10 & $33.3 \%$ \\
\hline Expressives & 5 & $16.7 \%$ \\
\hline Commissives & 3 & $10 \%$ \\
\hline Declarations & 0 & $0 \%$ \\
\hline Total & $\mathbf{3 0}$ & $\mathbf{1 0 0 \%}$ \\
\hline
\end{tabular}

Table 1 shows the frequency of utterances performed by T1. Based on the data, T1 used representatives 12 (40\%), directives $10(33.3 \%)$, expressives $5(16.7 \%)$, commissives $3(10 \%)$, and declarations $0(0 \%)$. Some examples of speech acts uttered by $\mathrm{T} 1$ are as follows:

Data 1: (This is the last activity - Representative — informing)

Data 2: (Share your comments with your colleagues - Directive - inviting)

Data 3: (Hello everyone - Expressive - greeting)

Data 4: (I will post multiple photos on our Facebook account - Commissive — promising)

Data 5: (Open your books page 2 - Directive - commanding)

Data 6: (There are some rules that you should know as students of this program-Representative - asserting)

Data 7: (I will give you five points - Commissive - promising)

Data 8: (Yes, I agree with your proposal - Representative - asserting)

Data 9: (Watch the video - Directive - commanding)

Data 10: (Very good. I really liked your story -Expressive - complementing)

\subsection{Second teacher's speech acts (T2)}

Table 2: The frequency and percentage of speech acts produced by $T 2$

\begin{tabular}{|l|c|c|}
\hline \multicolumn{1}{|c|}{ Type of speech acts } & Frequency of utterances & Total percentage \\
\hline Representatives & 5 & $16.7 \%$ \\
\hline Directives & 15 & $50 \%$ \\
\hline Expressives & 7 & $23.3 \%$ \\
\hline Commissives & 3 & $10 \%$ \\
\hline Declarations & 0 & $0 \%$ \\
\hline Total & $\mathbf{3 0}$ & $\mathbf{1 0 0 \%}$ \\
\hline
\end{tabular}

Table 2 shows the most dominant speech acts performed by T2. Based on the data, T2 used representatives $5(16.7 \%)$, directives $15(50 \%)$, expressives 7 (23.3\%), commissives $3(10 \%)$, and declarations $0(0 \%)$. Examples of utterances produced by $\mathrm{T} 2$ are as follows:

Data 1: (Here are the handouts for today's class - Representative - informing)

Data 2: (Join the discussion - Directive - commanding)

Data 3: (See you next week - Expressive - closing)

Data 4: (You are going to obtain extra points - Commissive - promising)

Data 5: (Well done - Expressive - complementing)

Data 6: (Please sit with your groups - Directive - ordering)

Data 7: (I will show you some cards - Commissive - promising)

Data 8: (Thank you - Expressive - thanking)

Data 9: (This is the last activity - Representative - informing)

Data 10: (If you want to remember the story, write it down on paper - Directive - suggestion) 
Table 3: Summary of speech acts performed by Access teachers

\begin{tabular}{|c|c|c|c|}
\hline Type of speech acts & \multicolumn{2}{|c|}{$\begin{array}{c}\text { Frequency of utterances } \\
\mathrm{T} 2 \text { and } \mathrm{T} 2\end{array}$} & Total percentage \\
\hline Representatives & 12 & 5 & $17(28.3 \%)$ \\
\hline Directives & 10 & 15 & $25(41.7 \%)$ \\
\hline Expressives & 5 & 7 & $12(20 \%)$ \\
\hline Commissives & 3 & 3 & $6(10 \%)$ \\
\hline Declarations & 0 & 0 & $0(0 \%)$ \\
\hline Total & 30 & 30 & $100 \%$ \\
\hline
\end{tabular}

Based on the findings, both Access teachers used speech acts in their utterances during the teaching-learning process. The table shows that both teachers used representatives 17 (28.3\%), directives $25(41.7 \%)$, expressives $12(20 \%)$, commissives $6(10 \%)$, and no declarations $0(0 \%)$.

\section{Discussion of findings}

After counting utterances performed by Access teachers in class, it can be seen that the number of directives is more prevalent than other speech acts (Namaziandost, Hashemifardnia, \& Hossein, 2019). Most speech acts were performed by teachers. This implies that the classroom was largely dominated by teachers (Kurdghelashvili, 2015). Regarding the first research question, "What is the most dominant speech act in utterances produced by T1? teacher's utterances showed that representative speech act was the most dominant act produced by $\mathrm{T} 1$. This result did not support the results of previous studies regarding representative speech act. The findings proved that the use of speech acts of illocutionary force, such as representative-assertive and directive was highly determined by the context of the situation (Bahing, Emzir, \& Rafli, 2018). From the collected data, the types of representative speech acts produced by T1 were informing, asserting, reporting, etc.

Regarding the second research question, "What is the most dominant speech act in utterances produced by T2? teachers' utterances showed that the illocution speech act of the directive was the most dominant (41.7\%). This result is consistent with those of previous studies (Andewil \& Waziana, 2019; Swandewi et al., 2018, Basra \& Thoyyibah, 2017; Rosyada, 2020). Directive speech acts produced by T1 were commanding, inviting, ordering, suggesting, etc. Directive speech acts are very useful for teachers because they are used to manage and control the students' behavior during the teaching and learning process (Andewi \& Wiziana, 2019, p.33). In addition, directives have a higher social status than other speech acts; teachers use directive acts to maintain control of the class (Siritman \& Meilantina, 2020, p.7).

Furthermore, the study showed results for other types of illocutionary acts. For example, commissive speech acts come in the form of promising, offering, etc. Also, the types of expressive speech acts were complementing, thanking, greeting, closing, etc. The study showed that both teachers did not produce declarations. To sum up, both teachers produced four types of illocutionary acts, namely directives, representatives, expressives, and commissives.

\section{Conclusion}

The goal of this study was to identify different types of speech acts performed by two Access teachers at Mati Logoreci Primary School. Frequency and percentage were used to determine which speech acts were used more frequently by Access teachers. Based on the findings and discussion, four classifications of illocutionary acts were identified from the data. Each classification had different percentages, with directive speech acts being the dominant one (Firdaus, 2020), followed by representatives $(28.3 \%)$, expressives $(20 \%)$, commissives $(6 \%)$, and declarations $(0 \%)$. The results showed that the declarative speech act was the least used. Furthermore, directive speech acts were the most dominant one used by both teachers to provide instructions.

The use of speech act cannot be avoided in the classroom because speech acts produced by teachers can make the students more active in the classroom (Swandewi, Ramendra, \& Juniarta, 2018). Therefore, teachers should practice more speech acts while teaching and interacting with their students. By doing so, they would help their students improve their pragmatic competence. This is very pivotal in an EFL context (Azhari, Priono, \& Nuriadi, 2018). To sum up, the findings of this study will provide more insights to readers concerning the study of speech in an EFL context (Christianto, 2020).

\subsection{Limitations of the study}

The limitations of this study include the number of teachers. This study observed only two teachers during the teaching-learning process. Therefore, the results of this study cannot be generalized to other teachers. Another limitation of this study is that it could not provide data for other teachers and students at Mati Logoreci Primary School. Furthermore, the researcher observed only two meetings. Thus, it would be better for other researchers to observe more meetings to obtain more reliable and valid data. 


\subsection{Recommendations for further research}

As previously mentioned, this study provided data regarding speech acts in EFL classrooms from only two teachers. Further studies could observe a larger number of teachers. Further research could be conducted by comparing the findings from this research to other settings (Thuruvan \&Yonus, 2017). In addition, other researchers could analyze speech acts produced by students in an EFL context.

\section{References}

Andewi, W., \& Wazianam, W. (2019). An analysis of teacher's speech acts in teaching. TEKNOSASTIK, 29-34.

Armin, S. D., \& Salmiah, M. (2020). Teacher's and students interaaction in EFL classroom. In Annual International Conference on Language and Literature (AICLL), KnE Social Sciences, 224-237.

Austin, J. (1962). How to do things with words: The William James Lectures delivered at Harward University in 1955. London: Oxford at the Clarendon Press.

Azhari, A. S., Priono,.-.,\& Nuriadi, .-. (2018). Speech acts of classroom interaction. International Journal of Linguistics, Literature and Culture, 4(2), 24-45.

-.Bahing, Emzir,.-., \& Rafli, Z. (2018). English speech acts of illocutionary force in class interaction. Australian International Academic Centre, 9(3), 73-81.

Basra, S. M., \& Thoyyibah, L. (2017). A speech act analysis of teacher talk in an EFL classroom. International Journal of Education, 10(1),73-81.

Budianti, A. P., Pahamzah, J., \& Baihaqi, A. (2020). Speech acts in teaching and learning process of English at LP31 Cilegon. CALR Linguistic Journal.

Chankova, M. (2012). Illocutionary acts: a case for assertion. (Doctoral Dissertation, Rheinisch- Westfälische Technische Hochschule Aachen).

Christianto, D. (2020). Speech acts in EFL classrooms. Journal of Pragmatics Research, 2(1), 68-79.

Dörnyei, Z. (2007). Research methods in applied linguistics: Quantitative, qualitative, and mixed methodologies. Oxford: Oxford University Press.

Dylgjeri, A. (2017). Analysis of speech acts in political speeches. European Journal of Social Sciences, 2(2), 1926.

Firdaus, R. M. (2020). Analysis of speech act classifications in EFL classroom interaction. Universitas Negeri Makassar. Retrieved from http://eprints.unm.ac.id/18685/

Kurdghelashvili, T. (2015). Speech acts and politeness strategies in an EFL classroom in Georgia. International Journal of Cognitive and Language Sciences, 9(1), 306-309.

Levinson, S. (1983). Pragmatics. UK: Cambridge University Press.

Merdana,-., Seken, K, \& Adi Yaya Putra, N. (2013). An analysis of speech acts produced by elementary school teachers and students to facilitate teaching and learning at sdn 10 pringgasela east Lombok. e-Journal Program Pascasarjana Universitas Pendidikan Ganesha Program Studi Pendidikan Bahasa Inggris, 1. DOI: https://doi.org/10.23887/jpbi.v1i0.723

Meyer, F. Ch. (2009). Introducing English linguistics. Cambridge: Cambridge University Press.

Namaziandost, E., Hashemifardnia, A., \& Hosseini, E. (2019). A survey of high schools English textbooks in terms of using varying types of speech acts. Applied Linguistics Research Journal, 3(4), 24-32.

Rosyada, M. (2020). Speech acts used by English lecturers in online teaching and learning process at study program of English language education, State Islamic University of Mataram (Bachelor's thesis, State Islamic University of Mataram).

Searle, J. R. (1969). Speech acts: An essay in the philosophy of language. Cambridge: Cambridge University Press.

Sejdiu, S. (2014). English language teaching and assessment in blended learning. Journal of Teaching and Learning with Technology, 3(1), 67-82.

Senft, G. (2014). Understanding pragmatics. New York: Routledge.

Shasqia, M., \& Anggraini, A. (2020). An investigation on how university students' view lecturers' usage of speech acts in ELT context. The journal of Ultimate Research and Trends in Education, 2(2), 39-43.

Shi, Y. (2018). A pragmatic study on English teachers' speech acts in universities. 8th International Conference on Social Network, Communication and Education (SNCE 2018), 89-92. Atlantis Press.

Siritman, B. M., \& Mailantina, M. (2020). English speech acts of directives in class interaction. International Journal of Language Education and Cultural Review (IJLECR), 6(1), 1-8.

Speech. (n.d.). In The Advanced Cambridge Dictionary. Retrieved from https:/dictionary.cambridge.org/dictionary/english/speech

Speech. (n.d.). In Longman Dictionary. Retrieved from https://www.ldoceonline.com/dictionary/speech

Swandewi, I. A., Ramendra, D.P., \& Juniarta, P.A. (2018). An analysis of speech acts used by English teachers in classroom teaching and learning process at SMA Negeri 2 Banjar. Jurnal Pendidikan Bahasa Inggris Undiksha, 5(2). 
Thuruvan, P., \& Yonus, M.M. (2017). The speech act of request in the ESL classroom. The Southeast Asian Journal of English Language Studies, 23(4), 212 - 221.

Tiwery, D. (2021). Comparative study on discourse analysis based on school's slogan. Jurnal Tahuri, 18(1), 4054. https://doi.org/10.30598/tahurivol18issuel page40-54

United States Department of State . (2004). Bureau of Educational and Cultural Affairs: Exchange programs. Retrieved from https://exchanges.state.gov/

Yule, G. (1996). Pragmatics. Cambridge University Press.

Yule, G. (2010). The study of language. Cambridge: Cambridge University Press. 